\title{
KiSS1/GPR54 and estrogen-related gene expression profiles in primary breast cancer
}

\author{
KATARZYNA JARZĄBEK ${ }^{1,2}$, LESZEK KOZŁOWSKI ${ }^{3}$, ROBERT MILEWSKI $^{4}$ and SŁAWOMIR WOŁCZYŃSKI ${ }^{1,2}$ \\ ${ }^{1}$ Department of Reproduction and Gynecological Endocrinology, Medical University of Bialystok; \\ ${ }^{2}$ Department of Biology and Pathology of Human Reproduction in Bialystok, Institute of Animal Reproduction \\ and Food Research, Polish Academy of Science, Olsztyn; ${ }^{3}$ Department of Surgical Oncology, Internal Affairs Hospital, \\ Bialystok; ${ }^{4}$ Department of Statistics and Medical Informatics, Medical University of Bialystok, Bialystok 15-276, Poland
}

Received November 4, 2011; Accepted January 18, 2012

DOI: $10.3892 / \mathrm{ol} .2012 .582$

\begin{abstract}
The estrogen receptor $\alpha(\mathrm{ER} \alpha)$-mediated pathway plays a critical role in breast cancer development and progression. KiSS1 was previously described as a metastasis suppressor gene in certain carcinomas. However, the role of KiSS1/GPR 54 in breast cancer remains controversial. Whether the function of the KiSS1/GPR54 system depends on estrogen signaling in the breast cancer cell remains to be determined. This study aimed to determine the expression profiles of the KiSS1/GPR54, ER $\alpha, E R \beta$, aromatase and cyclin D1 genes in human breast cancer tissues, and to identify a possible link between the expression levels of the studied genes and the selected clinical and pathological features. The study subjects comprised 59 females treated surgically for primary breast cancer. Total RNA was extracted from frozen breast cancer tissues, and expression levels were examined to determine any correlations. We observed strong positive correlations between the expression levels of the studied genes. The expression of $\mathrm{ER} \alpha$ correlated positively with progesterone receptors (PRs), and in these tumors we also observed positive correlations between KiSS1, GPR54 and cyclin D1 mRNAs and the ER $\alpha$ protein. ER-positive breast tumors exhibited higher KiSS1 and GPR54 levels than the ER-negative tumors. The expression levels of the ER $\alpha$ and GPR54 transcripts were higher in the moderately differentiated tumors (G2) compared to the poorly differentiated high-grade (G3) cancers. We also found that HER-2/neu status in breast cancer is negatively associated with GPR54 mRNA expression. Decreasing GPR54 mRNA expression levels in HER-2/neu (+) tumors may be associated with the deregulation of the classical estrogenmediated signaling pathway in breast tumors, and therefore, with promotion of tumor invasiveness. Our findings indicate
\end{abstract}

Correspondence to: Dr Katarzyna Jarzabek, Department of Reproduction and Gynecological Endocrinology, Medical University of Bialystok, Sklodowskiej 24A, Bialystok 15-276, Poland

E-mail: kasia.jarzabek@gmail.com

Key words: KiSS1/GPR54, estrogen receptors, HER-2/neu, breast cancer that genes involved in the KiSS1/GPR54 system, as well as in the estrogen signaling pathway, may be utilizable molecular factors in pathogenesis studies of breast cancer.

\section{Introduction}

Recent studies have focused attention on the KiSS1/GPR54 system in tumor biology, particularly concerning the regulation of progression and metastasis processes. The majority of cancer mortalities are due to complications resulting from tumor cell metastasis rather than primary tumor growth. Cancer research has focused on identifying metastatic suppressors and blocking the metastatic process in the early stages. The first described role for KiSS1 was associated with its metastasis inhibitory potential in melanoma $(1,2)$. KiSS1 has also been suggested as a potential metastasis suppressor in breast cancer cells, regulating events downstream of cell-matrix adhesion, without affecting tumorigenicity (3).

The physiological and biological functions of KiSS1 have recently been examined. KiSS1 and GPR54 play a pivotal role in reproduction and puberty, regulating the hypothalamicpituitary-gonadal axis $(4,5)$. The KiSS1/GPR54 system is also involved in the placentation and trophoblast invasion, an essential process for fetal development, which closely mimics the invasion of cancer cells $(6,7)$. Binding of kisspeptin to GPR54 triggers a few intracellular signaling pathways resulting in arachidonic acid release, and ERK1/2 and p38 activation (8). Binding of KiSS1 to GPR54 may downregulate their expression via a feedback mechanism (7). Notably, despite activation of the ERK signaling pathway, kisspeptins markedly inhibit the proliferation rate of cells expressing GPR54; however, the pathway responsible for this proliferation rate remains to be elucidated (8)

The estrogen receptor $\alpha(\mathrm{ER} \alpha)$-mediated pathway is known to play a key role in the genesis and progression of breast cancer. Moreover, the ER $\alpha$ level is a prognostic marker for breast tumors and a predictive factor of the response to endocrine therapy (9). Marot et al studied human breast cancer tumors and hypothesized that KiSS1 and GPR54 are estrogenregulated genes, and that their expression levels in these tumors should be analyzed, taking into account the expression profile and status of ER $\alpha$ (10). However, the precise mechanism, 
explaining the role of KiSS1/GPR54 in breast cancer cells and their loss or overexpression during metastasis, remains unknown. Upon cancer cells acquiring metastatic potential, expression levels of various genes contributing to the cell cycle, tumor cell invasion and migratory properties are altered. Genes commonly found to be upregulated in breast tumors, including aromatase, cyclin D1, c-myc and matrix metalloproteinase-9 mediate the behavioral and proliferative changes that stimulate oncogenesis (11-15). Data from the ovine hypothalamus suggest that estradiol (E)2, through $E R \alpha$, is capable of exerting a direct effect on kisspeptin-immunoreactive cells (16). Whether the function of the KiSS1/GPR54 system depends on estrogen signaling in breast cancer cells remains to be elucidated. This study aimed to determine the expression profiles of KiSS1/GPR54, ER $\alpha, E R \beta$, aromatase and cyclin D1 genes in human breast cancer tissues, and identify a possible link between the expression levels of the studied genes and the selected clinical and pathological features.

\section{Materials and methods}

Patients and samples. Breast cancer samples were collected from 59 females following surgical treatment, frozen in liquid nitrogen and maintained at $-80^{\circ} \mathrm{C}$ until molecular analysis was performed. Tumor samples were also fixed in $10 \%(\mathrm{v} / \mathrm{v})$ buffered formaldehyde solution for $48 \mathrm{~h}$ and then embedded in paraffin blocks at $56^{\circ} \mathrm{C}$ according to standard procedures.

Tumor samples were cut into $5-\mu \mathrm{m}$ sections and stained with hematoxylin and eosin. Histopathological examination was based on the WHO and pTN classification of breast tumors (17). The study comprised invasive ductal carcinomas, representing G2 (32 patients) and G3 (18 patients) grades, and lobular carcinomas (9 patients). Histopathological grading (G) was performed according to the Bloom and Richardson system (18). Patients had not received any preoperative chemo- or hormonotherapy. The present study was approval by the Ethics Committee for Human Studies of the Medical University of Bialystok, Poland. All of patients were informed of this study and consented to participation.

RNA extraction and cDNA synthesis. Total RNA was extracted from frozen breast cancer tissues according to the Chomczynski and Sacchi method (19). RNA integrity was verified using electrophoresis in $1.5 \%(\mathrm{w} / \mathrm{v})$ agarose gel, staining with ethidium bromide, and amplification of the housekeeping gene, 18s rRNA. RNA was quantified spectrophotometrically at $260 \mathrm{~nm}$. Total RNA $(1 \mu \mathrm{g})$ was used to prepare the cDNA. cDNA synthesis was performed in $50 \mathrm{mM}$ Tris- $\mathrm{HCl}(\mathrm{pH} 8.3)$, $75 \mathrm{mM} \mathrm{KCl}, 3 \mathrm{mM} \mathrm{MgCl}{ }_{2}, 10 \mathrm{mM}$ DTT, $1 \mathrm{mM}$ dNTP mix (Promega, Madison, WI, USA), $2.5 \mu \mathrm{M}$ oligo dT15, 20 units RNasin ribonuclease inhibitor (Promega) and 100 units MMLV reverse transcriptase (Promega) at a final volume of $40 \mu 1$ using an MJ Research thermal cycler (Model PTC-200, Watertown, MA, USA). For reverse transcription, the mixtures were incubated at $42^{\circ} \mathrm{C}$ for $60 \mathrm{~min}$ and then heated to $95^{\circ} \mathrm{C}$ for $5 \mathrm{~min}$ and finally rapidly cooled to $4^{\circ} \mathrm{C}$.

Quantitative-real-time-PCR (Q-RT-PCR). To determine the expression levels of KiSS1, GPR54, ER $\alpha, E R \beta$, aromatase and cyclin D1, standard curves for each gene were constructed sepa- rately using serially diluted PCR products. PCR products were obtained by amplification of cDNA from MCF-7 cells using specific primers (Table I). PCR was conducted in a final volume of $50 \mu \mathrm{l}$ using $25 \mathrm{pmol}$ of each of the primers, $40 \mu \mathrm{M}$ of each of dNTPs, 1.5 units Taq polymerase (Finnzymes, Finland), $5 \mu \mathrm{l}$ 10 -fold PCR buffer and $5 \mu \mathrm{lcDNA}$.PCR was conducted under the following conditions: $5 \mathrm{~min}$ at $95^{\circ} \mathrm{C}, 1 \mathrm{~min}$ denaturation at $95^{\circ} \mathrm{C}$, 1 min annealing at $60^{\circ} \mathrm{C}, 1 \mathrm{~min}$ extension at $72^{\circ} \mathrm{C}$ for 40 cycles, with an additional $10 \mathrm{~min}$ extension for the last cycle. Amplified products were separated on a $2 \%(\mathrm{w} / \mathrm{v})$ agarose gel, extracted and purified from agarose slices using a DNA gel extraction kit (Millipore, Billerica, MA, USA), quantified by the use of One Dscan/Zero Dscan software (Scanalytics Inc., Rockville, MD, USA), and then serially diluted in sterile water.

To determine the mRNA levels of the studied genes, we used an Assays-on-Demand Gene Expression Assay mix (Applied Biosystems, Carlsbad, CA, USA). The Q-RT-PCR reactions were performed using an ABI Prism 7700 Sequence Detection System (Applied Biosystems). For each PCR run, a master mix was prepared using $10 \mu 12 \mathrm{X}$ TaqMan Gene Expression PCR Master mix (Applied Biosystems), $1 \mu \mathrm{l}$ 20X Assays-on-Demand Gene Expression Assay mix (Applied Biosystems), $5 \mu \mathrm{cDNA}$ and sterile water at a final volume of $20 \mu \mathrm{l}$. The relative quantification was given by the ratio between the mean value of the target gene and the mean value of the reference gene (18s rRNA) for each sample.

Evaluation of ER, progesterone receptor and HER-2/neu status. For evaluation of the ER, progesterone receptor (PR) and HER-2/neu status, two representative sections from each breast cancer tissue were selected. The procedure was conducted according to the Ventena Medical System, CONFIRM, and was applied as a routine diagnostic tool (Ventena Medical System, Tucson, AZ, USA). The ER, PR and HER-2/neu stains were conducted under the conditions recommended by the manufacturer. The following systems were used: CONFIRM anti-ER (SP1) for the estrogen receptor $\alpha$, CONFIRM anti-PR (1E2) for the progesterone receptor and PATHWAY HER-2/neu (4B5) for the evaluation of the c-erbB02 oncoprotein.

Statistical analysis. The mean values \pm standard deviation (SD) were calculated. The normal distribution was verified using the Kolmogorov-Smirnov test with correction by the Lilliefors test and the Shapiro-Wilk test. To compare the differences between the two populations, the Mann-Whitney U test was used. The Spearman's rank correlation coefficient was also estimated. The analysis was performed using the statistical software package StatSoft Statistica 8.0, with $\mathrm{p}<0.05$ indicating a statistically significant difference.

\section{Results}

Expression profiles of KiSS1, GPR54, ER $\alpha, E R \beta$, aromatase and cyclin D1. To evaluate the level of KiSS1, GPR54, ER $\alpha$, ER $\beta$, aromatase and cyclin D1 mRNA expression, Q-RT-PCR with manually prepared curves was used. The results obtained (in fg or attg for aromatase) were converted to fmol/attmol of transcript per $\mu \mathrm{g}$ of total RNA, and then normalized by the level of 18s rRNA. All of the studied tumors expressed ER $\alpha$, KiSS1 and cyclin D1 mRNAs. Only 1 of 59 tumors did not 
Table I. Primers used for construction of the standard curves according to the Q-RT-PCR method.

\begin{tabular}{lll}
\hline Gene name & \multicolumn{1}{c}{ Forward primers } & \multicolumn{1}{c}{ Reverse primers } \\
\hline KiSS1 & 5'TGAACTCACTGGTTTCTTGGC3' & 5'CAGCCTGGCAGTAGCAGCT3' \\
GPR54 & 5'ATCTACGTCATCTGCCGCCAC3' & 5'TCACGTACCAGCGGTCCACAC3' \\
ER $\alpha$ & 5'TGCTTCAGGCTACCATTATGGAGTCTG3' & 5'GTCAGGGACAAGGCCAGGCTG3' \\
ER $\beta$ & 5'TTTAAAAGAAGCATTCAAGGACATAATG3' & 5'CGGTGAAGGGCGCACTG3' \\
Aromatase & 5'GCCACTGAGTTGATTTTAGC3' & 5'CCAAATGGCTGAAAGTACC3' \\
Cyclin D1 & 5'GTCGCTGGAGCCCGTGAAAA3' & 5'ACGAAGGTCTGCGCGTGTTTG3' \\
18s rRNA & 5'CGTCTGCCCTATCAACTTTCG3' & 5'CGCGGTCCTATTCCATTATTC3'
\end{tabular}

Q-RT-PCR, quantitative-real-time-polymerase chain reaction.

Table II. Analysis of the correlations between the studied transcripts in 59 breast tumor samples using the Spearman's rank correlation test. ${ }^{\mathrm{a}}$

\begin{tabular}{llll}
\hline Analyzed genes & $\mathrm{n}$ & $\mathrm{r}$ & P-value \\
\hline ER $\alpha$ and ER $\beta$ & 59 & 0.4 & 0.0004 \\
ER $\alpha$ and KiSS1 & 59 & 0.6 & 0.000003 \\
ER $\alpha$ and GPR54 & 59 & 0.6 & 0.000001 \\
ER $\alpha$ and cyclin D1 & 59 & 0.7 & 0.000000 \\
ER $\alpha$ and aromatase & 59 & 0.3 & 0.03 \\
ER $\beta$ and KiSS1 & 59 & 0.7 & 0.000000 \\
ER $\beta$ and cyclin D1 & 59 & 0.6 & 0.000002 \\
ER $\beta$ and aromatase & 59 & 0.5 & 0.000005 \\
KiSS1 and cyclin D1 & 59 & 0.6 & 0.000000 \\
KiSS1 and aromatase & 59 & 0.5 & 0.000009 \\
GPR54 and cyclin D1 & 59 & 0.3 & 0.007 \\
Cyclin D1 and aromatase & 59 & 0.5 & 0.0002 \\
\hline
\end{tabular}

${ }^{\mathrm{a}} \mathrm{P}<0.05$. n, number of samples; $\mathrm{r}$, Spearman's rank correlation coefficient.

demonstrate ER $\beta$ mRNA expression and 2 of 59 tumors did not express the GPR54 transcript. The studied samples demonstrated the highest values of ER $\alpha$ and cyclin D1 transcript levels (mean 1495.7 \pm SD 2310.8; mean 1160.4 \pm SD 1372.0, respectively). ER $\beta$ transcripts for the breast tissue samples presented a 100-fold lower level (mean 15.9 \pm SD 65.2) compared to the ER $\alpha$ expression level. Aromatase was expressed at the lowest transcriptional attomolar level compared to the other studied genes expressed at the femtomolar levels (mean 5.7 \pm SD 17.9 attomolar level).

We also observed marked positive correlations between analyzed transcript levels (Table II).

Correlations of KiSS1, GPR54, ER $\alpha, E R \beta$, aromatase and cyclin D1 expression with selected clinical and pathological features. ER $\alpha$ expression at the mRNA level correlated positively with the age of the patients $(\mathrm{p}<0.03, \mathrm{R}=0.3)$. Statistically negative correlations were found between the tumor size (pT) and the levels of KiSS1, ER $\beta$ and cyclin D1 transcripts $(\mathrm{p}<0.02, \mathrm{r}=-0.3 ; \mathrm{p}<0.02, \mathrm{r}=-0.3 ; \mathrm{p}<0.002, \mathrm{r}=-0.4$, respectively). No association was detected between the studied genes expression levels and the lymph node status $(\mathrm{pN})$. However, the expression of ER $\alpha$ and GPR54 was found to be associated with tumor differentiation $(\mathrm{G})(\mathrm{p}<0.008 ; \mathrm{p}<0.02$, respectively). We observed statistically significant differences in the ER $\alpha$ and GPR54 expression levels between the G2 and G3 ductal tumors $(n=50)$. The expression levels of these two transcripts were higher in the moderately differentiated tumors (G2) compared to the poorly differentiated high-grade (G3) cancers (Fig. 1A).

Correlations of KiSS1, GPR54, ER $\alpha, E R \beta$, aromatase and cyclin D1 expression with ER, PR and HER-2/neu status. The ER-positive breast tumors exhibited higher KiSS1 and GPR54 levels than the ER-negative tumors (Fig. 1B). KiSS1, GPR54, ER $\alpha$ and cyclin D1 were positively correlated with ER status $(\mathrm{p}<0.01, \mathrm{r}=0,3 ; \mathrm{p}<0.001, \mathrm{r}=0.4 ; \mathrm{p}<0.000001, \mathrm{r}=7$; $\mathrm{p}<0.004, \mathrm{r}=0.4$, respectively). Positive correlations were found between the KiSS1, GPR54, ER $\alpha$ and cyclin D1 mRNA levels and the PR status $(\mathrm{p}<0.03, \mathrm{r}=0.3 ; \mathrm{p}<0.007$, $\mathrm{r}=0.3 ; \mathrm{p}<0.000001, \mathrm{r}=6 ; \mathrm{p}<0.003, \mathrm{r}=-0.3$, respectively). GPR54 mRNA levels negatively correlated with the HER-2/neu status $(\mathrm{p}<0.01, \mathrm{r}=-0.3)$. The GPR54 level was significantly higher in the HER-2/neu (-) tumors compared to the HER-2/neu (+) tumors (Fig. 1C).

\section{Discussion}

At present, the molecular profiles of primary breast tumors examined have demonstrated that there is a vast diversity between individual breast cancer tissues. Moreover, breast tumor biology has been revealed to be under hormonal regulation; this intratumoral hormonal environment could uniquely regulate the genes expressed in breast tissue. Following tumor progression and the acquisition of the malignancy and metastatic potential of cancer cells, the metastatic cascade is triggered. In light of recent data, metastasis suppressors play a key role as intermediaries between environmental signals and the tumor cell response to these stimuli, leading to metastasis (20).

Data from KiSS1/GPR54 system studies in the reproductive axis and hepatocellular and breast cancers have provided evidence that the function of this system is sensitive to steroid control $(3,5,21,22)$.

In the present study, the molecular profiles of the breast cancer tissues were examined and the expression levels of $\mathrm{ER} \alpha, \mathrm{ER} \beta$, aromatase, KiSS1/GPR54 and cyclin D1 were assessed. The positive correlations noted between the analyzed 
A

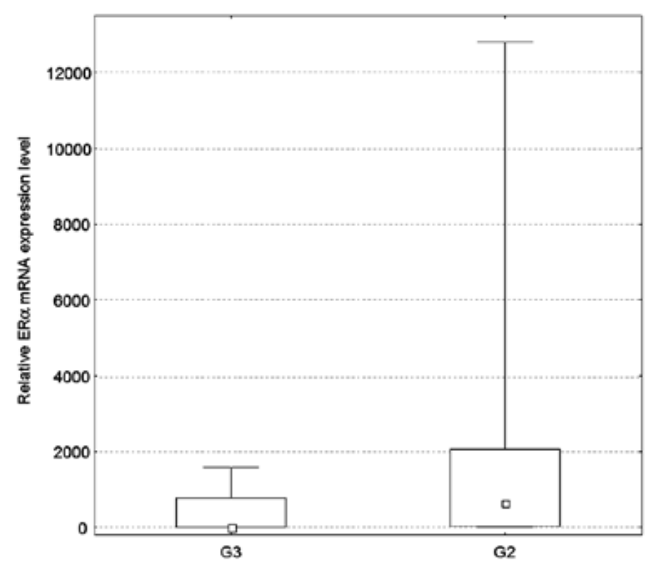

B

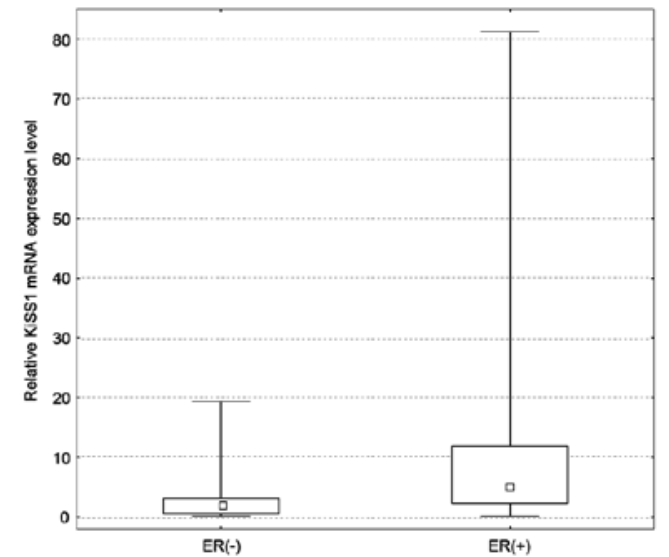

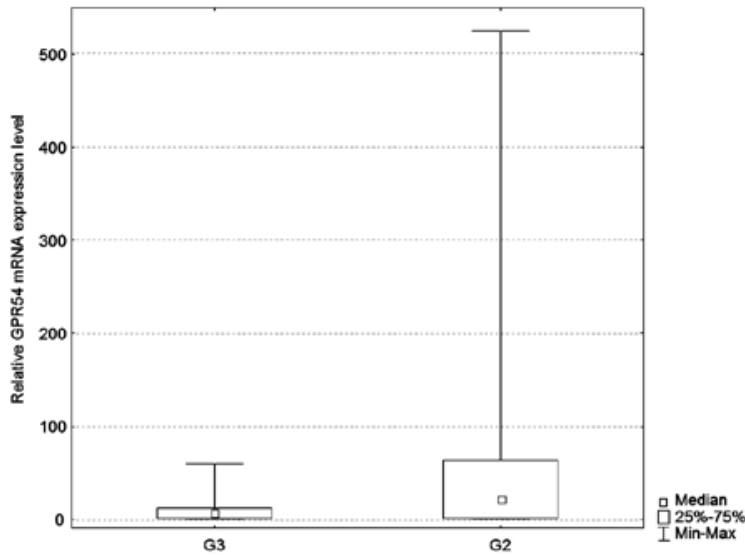

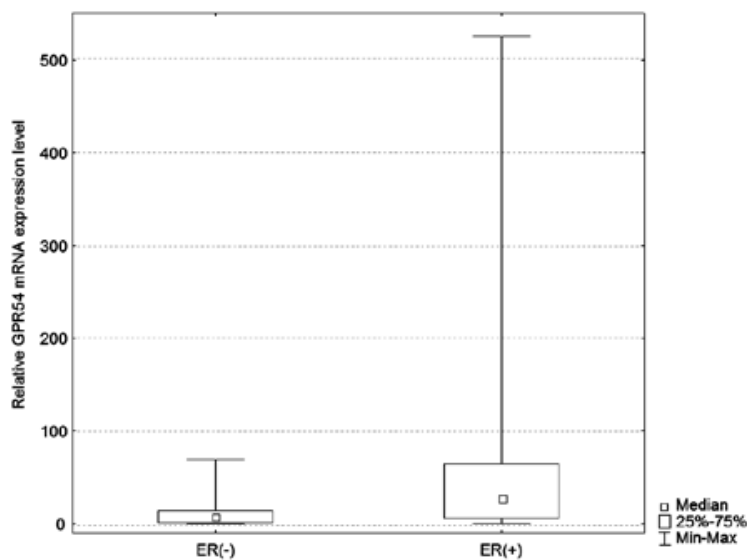

C

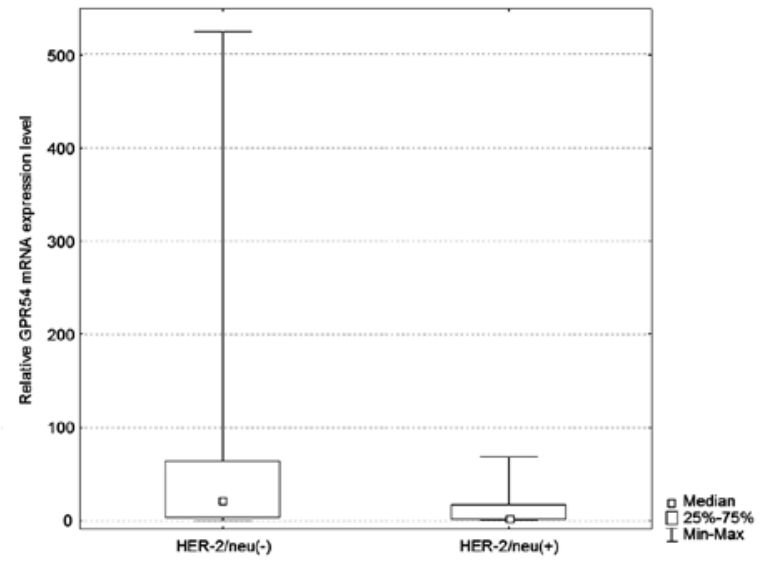

Figure 1. Results of the Mann-Whitney U test show the differences between the G3 and G2 grade tumors at a statistically significant level. (A) The expression levels of the ER $\alpha$ and GPR54 transcripts are lower in the poorly differentiated high-grade (G3) cancers compared to the moderately differentiated tumors (G2). (B) Higher KiSS1 and GPR54 expression levels were found in ER (+) breast tumors compared to the ER (-) tumors. (C) The GPR54 level is significantly higher in the HER-2/neu (-) tumors compared to the HER-2/neu (+) tumors.

transcripts (Table II) support the hypothesis that the genes coding KiSS1/GPR54, aromatase and cyclin D1 exhibit similar factors and/or estradiol regulations.

It has been well established in E2-elevated KiSS1 mRNA expression in ER (+) GT1-7 hypothalamic cell lines that high estradiol levels activate ER $\alpha$ and the SP protein complex, which in turn bind to the KiSS1 promoter region leading to KiSS1 upregulation (23). However, the question arises as to whether the same regulation is possible in breast cancer. It is well known that estrogen synthesis in breast cancer tissues in postmenopausal women is due to in situ tumor aromatase expression.
Using Q-RT-PCR, the presence of the aromatase transcript was detected in all analyzed breast tumors. Moreover, the KiSS1 and GPR54 expression levels were higher in the ER-positive compared to in the ER-negative tumors. These data do not confirm the results of a study conducted by Marot et al, in which KiSS1 expression was negatively associated with ER $\alpha$ status (10). These authors also concluded that a high KiSS1 expression in ER $\alpha(+)$ breast tumors cells with poor prognosis may reflect hormonal resistance to E2. No associations between the KiSS1 expression level and the tumor grade were observed, in contrast to the findings by 
Martin et al who found that the KiSS1 level increased with tumor progression, and GPR54 expression increased in the invasive ductal tumor (24). However, in our study, in the ductal breast cancers $(n=50)$ group, higher levels of ER $\alpha$ and GPR54 mRNAs were observed in the G2-differentiated tumors compared to the G3 cancers. The role of GPR54 in breast cancer biology and metastasis phenotype has been difficult to determine. There are certain conflicting data disputing the role of GPR54 as a mediator responsible for an antimetastatic effect. Nash et al hypothesized that KiSS1 was capable of suppressing metastasis in the apparent absence of GPR54 in tumor cells, suggesting the existence of additional KiSS1 metastasis suppressor receptors and signaling pathways (25). Another study conducted by Zajac et al suggested that KiSS1/GPR54 signaling is pro-migratory and invasive in breast cancer cells. Furthermore, these authors maintained that GPR54 signaling through EGFR cross-talk was able to positively regulate breast cancer cell invasiveness (26). The results from this in vitro study do not confirm data from the present study. A lower GPR54 mRNA expression level was observed in the HER-2/neu-positive tumors compared to the HER-2/neu-negative tumors. Our study is not in accordance with certain results based on isolated in vitro systems used for evaluating the role of KiSS1/GPR54 signaling in metastasis in breast carcinomas. It appears that individual tissues of breast cancer are a greatly heterogeneous group to study, with increased intratumoral environmental components and varying hormonal regulation compared with that of in vitro cell lines. The possible correlation between estrogen status and KiSS1/GPR54 expression in breast cancer has revealed new possibilities of finding increased targeted therapies, in order to, in the future, modify the most systemic therapies in breast cancer based on blockage of the ER-dependent pathway.

\section{Acknowledgements}

This study was supported by the Polish Ministry of Science and Higher Education (grant no. N N407 090535).

\section{References}

1. Lee JH, Miele ME, Hicks DJ, Phillips KK, Trent JM, Weissman BE and Welch DR: KiSS-1, a novel human malignant melanoma metastasis-suppressor gene. J Natl Cancer Inst 88: 1731-1737, 1996.

2. Lee JH and Welch DR: Identification of highly expressed genes in metastasis-suppressed chromosome 6/human malignant melanoma hybrid cells using subtractive hybridization and differential display. Int J Cancer 71: 1035-1044, 1997.

3. Lee JH and Welch DR: Suppression of metastasis in human breast carcinoma MDA-MB-435 cells after transfection with the metastasis suppressor gene, KiSS-1. Cancer Res 57: 2384-2387, 1997.

4. De Roux N, Genin E, Carel JC, Matsuda F, Chaussain JL and Milgrom E: Hypogonadotropic hypogonadism due to loss of function of the KiSS1-derived peptide receptor GPR54. Proc Natl Acad Sci USA 100: 10972-10976, 2003.

5. Seminara SB, Messager S, Chatzidaki EE, Thresher RR, Acierno JS Jr, Shagoury JK, Bo-Abbas Y, Kuohung W, Schwinof KM, Hendrick AG, et al: The GPR54 gene as a regulator of puberty. N Engl J Med 349: 1614-1627, 2003.

6. Janneau JL, Maldonado-Estrada J, Tachdjian G, Miran I, Motté N, Saulnier P, Sabourin JC, Coté JF, Simon B, Frydman R, et al: Transcriptional expression of genes involved in cell invasion and migration by normal and tumoral trophoblast cells. J Clin Endocrinol Metab 87: 5336-5339, 2002.
7. Hiden U, Bilban M, Knöfler M and Desoye G: Kisspeptins and the placenta: regulation of trophoblast invasion. Rev Endocr Metab Disord 8: 31-39, 2007.

8. Kotani M, Detheux M, Vandenbogaerde A, Communi D, Vanderwinden JM, Le Poul E, Brézillon S, Tyldesley R, Suarez-Huerta N, Vandeput F, et al: The metastasis suppressor gene KiSS-1 encodes kisspeptins, the natural ligands of the orphan G protein-coupled receptor GPR54. J Biol Chem 276: 34631-34636, 2001.

9. Clarke RB, Anderson E and Howell A: Steroid receptors in human breast cancer. Trends Endocrinol Metab 15: 316-323, 2004.

10. Marot D, Bieche I, Aumas C, Esselin S, Bouquet C, Vacher S, Lazennec G, Perricaudet M, Kuttenn F, Lidereau R, et al: High tumoral levels of Kiss 1 and G-protein-coupled receptor 54 expression are correlated with poor prognosis of estrogen receptor-positive breast tumors. Endocr Relat Cancer 14: 691-702, 2007.

11. Gillett C, Smith P, Gregory W, Richards M, Millis R, Peters G and Barnes D: Cyclin D1 and prognosis in human breast cancer. Int J Cancer 69: 92-99, 1996.

12. Yu Q, Geng Y and Sicinski P: Specific protection against breast cancers by cyclin D1 ablation. Nature 411: 1017-1021, 2001.

13. Wang YH, Liu S, Zhang G, Zhou CQ, Zhu HX, Zhou XB, Quan LP, Bai JF and Xu NZ: Knockdown of c-Myc expression by RNAi inhibits MCF-7 breast tumor cells growth in vitro and in vivo. Breast Cancer Res 7: R220-R228, 2005.

14. Stuelten CH, DaCosta Byfield S, Arany PR, Karpova TS, Stetler-Stevenson WG and Roberts AB: Breast cancer cells induce stromal fibroblasts to express MMP-9 via secretion of TNF-alpha and TGF-beta. J Cell Sci 118: 2143-2153, 2005.

15. Jarzabek K, Koda M, Kozlowski L, Sulkowski S, Kottler ML and Wolczynski S: The significance of the expression of ERRalpha as a potential biomarker in breast cancer. Steroid Biochem Mol Biol 113: 127-133, 2009.

16. Franceschini I, Lomet D, Cateau M, Delsol G, Tillet Y and Caraty A: Kisspeptin immunoreactive cells of the ovine preoptic area and arcuate nucleus co-express estrogen receptor alpha. Neurosci Lett 401: 225-230, 2006.

17. Tavassoli FA and Devilee P (eds): Pathology and Genetics of Tumours of the Breast and Female Genital Organs. WHO Classification of Tumours series. IARC Press, Lyon, pp9-59, 2003.

18. Bloom HJG and Richardson WW: Histological grading and prognosis in breast cancer. Br J Cancer 11: 359-377, 1957.

19. Chomczynski P and Sacchi N: Single-step method of RNA isolation by acid guanidinium thiocyanate-phenol-chloroform extraction. Anal Biochem 162: 156-159, 1987.

20. Cook LM, Hurst DR and Welch DR: Metastasis suppressors and the tumor microenvironment. Semin Cancer Biol 21: 113-122, 2011.

21. Ikeguchi M, Hirooka Y and Kaibara N: Quantitative reverse transcriptase polymerase chain reaction analysis for KiSS-1 and orphan G-protein-coupled receptor (hOT7T175) gene expression in hepatocellular carcinoma. J Cancer Res Clin Oncol 129: $531-535,2003$.

22. Schmid K, Wang X, Haitel A, Sieghart W, Peck-Radosavljevic M, Bodingbauer M, Rasoul-Rockenschaub S and Wrba F: KiSS-1 overexpression as an independent prognostic marker in hepatocellular carcinoma: an immunohistochemical study. Virchows Arch 450: 143-149, 2007.

23. Li D, Mitchell D, Luo J, Yi Z, Cho SG, Guo J, Li X, Ning G, Wu X and Liu M: Estrogen regulates KiSS1 gene expression through estrogen receptor alpha and SP protein complexes. Endocrinology 148: 4821-4828, 2007.

24. Martin TA, Watkins G and Jiang WG: KiSS-1 expression in human breast cancer. Clin Exp Metastasis 22: 503-511, 2005.

25. Nash KT,PhadkePA, Navenot JM,Hurst DR,Accavitti-Loper MA, Sztul E, Vaidya KS, Frost AR, Kappes JC, Peiper SC, et al: Requirement of KISS1 secretion for multiple organ metastasis suppression and maintenance of tumor dormancy. J Natl Cancer Inst 99: 309-321, 2007.

26. Zajac M, Law J, Cvetkovic DD, Pampillo M, McColl L, Pape C, Di Guglielmo GM, Postovit LM, Babwah AV and Bhattacharya M: GPR54 (KISS1R) transactivates EGFR to promote breast cancer cell invasiveness. PLoS One 6: e21599, 2011. 